\title{
1 \\ THE CULTURAL JOURNEYS OF DICTIONARIES OF BIOGRAPHY
}

\author{
KAREN FOX
}

Fifty years after the publication of the first volume of the Australian Dictionary of Biography, in mid-2016 participants from around the English-speaking world gathered in Canberra for the conference "'True Biographies of Nations"? Exploring the Cultural Journeys of Dictionaries of National Biography'. ${ }^{1}$ Organised by the National Centre of Biography at The Australian National University (ANU) and supported by the National Library of Australia (NLA), the conference provided a rare opportunity for those involved in the production of dictionaries of national biography to come together, along with archivists, librarians, fellow researchers, and members of the public, to reflect on the purpose and place of national biographies in the twenty-first century. The aim was to explore the cultural journeys taken by dictionaries of national biography, to consider the challenges and opportunities facing such projects today, and to gauge the extent of their development into truly national biographies.

Thematically and institutionally the 2016 gathering was the sequel to an earlier conference on national biographies, organised by the Humanities Research Centre and the Australian Dictionary of Biography at ANU, and the NLA, and held in Canberra in 1995. Setting out to 'explore the literary and historical character of the genre' of national biography, and to

1 The term 'cultural journey' is also used in relation to dictionaries of national biography by Marcello Verga. Marcello Verga, 'The Dictionary is Dead, Long Live the Dictionary! Biographical Collections in National Contexts', in Setting the Standards: Institutions, Networks and Communities of National Historiography, eds Ilaria Porciani and Jo Tollebeek (Houndmills and New York: Palgrave Macmillan, 2012), 89. 
'compare a variety of its modern manifestations', it took place over three days, with the proceedings published as National Biographies and National Identity: A Critical Approach to Theory and Editorial Practice. ${ }^{2}$ Musing on the genre in the introduction to the collection, Iain McCalman suggested that the genre of the national biographical dictionary stood at the heart of the most ferocious and divisive contemporary debates about the epistemology and hermeneutics of knowledge'. ${ }^{3}$ In the late twentiethcentury context of fracturing national identities and the assertion of multiculturalism and multilingualism in Europe and the antipodes, he stated, ' $[\mathrm{m}]$ akers of national biographies stand in the front line of these identity wars."

McCalman's characterisation of dictionaries of national biography as prisms through which debates over identity-national, global, or even individual-are refracted remains pertinent 20 years later. Many of the issues discussed at the earlier conference, and in the resulting collection of papers, involved questions about the nation: its composition, its meanings, or its future. James Walter asked 'seven questions' of national biography, including how well such works could encapsulate 'the imaginative life of the nation' or embody the whole community rather than merely elites within a society, and what role collective biography plays in nation building. ${ }^{5}$ Focusing on female lives, Patricia Grimshaw too considered 'the tradition of nation-making', suggesting that recording women's significance in these processes required understanding 'the racial and gender dimensions of the construction of the idea of "nation", as well as the ways in which women were themselves 'enmeshed in' that idea. ${ }^{6}$ Elizabeth Baigent reflected upon the nation not only as the 'subject matter' of dictionaries of national biography, but also as its 'audience' and 'sponsor', exploring not only 'how ideas of the nation, nationality and national life are constructed [and] reconstructed', but also how those same ideas and processes can restrict possibilities for dictionary producers. ${ }^{7}$

2 Iain McCalman, 'Introduction', in National Biographies and National Identity: A Critical Approach to Theory and Editorial Practice, eds Iain McCalman with Jodi Parvey and Misty Cook (Canberra: Humanities Research Centre, The Australian National University, 1996), iii.

3 McCalman, 'Introduction', i.

4 McCalman, 'Introduction', i.

5 James Walter, 'Seven Questions About National Biography', in McCalman with Parvey and Cook, National Biographies and National Identity, 21-22, 31-34.

6 Patricia Grimshaw, 'Female Lives and the Tradition of Nation-Making', in McCalman with Parvey and Cook, National Biographies and National Identity, 53.

7 Elizabeth Baigent, 'Nationality and Dictionaries of National Biography', in McCalman with Parvey and Cook, National Biographies and National Identity, 63. 
And, as is always the case when those involved in biographical dictionary projects congregate, there was discussion of the numerous practical difficulties involved in such work-among them issues of selectivity and space, editorial decisions, funding, and revisions. Each of these matters, in different ways, finds resonance in the present book.

In a sense, the question that lay behind the 1995 conference was one recently highlighted by Marcello Verga: what is a dictionary of national biography for? According to Verga, the genre has been 'undergoing a steady transformation', from being 'an instrument designed to vindicate past glories and national supremacy', to developing as 'a learned and specialised work without the earlier ideological overtones'. ${ }^{8}$ Certainly, dictionaries of national biography have changed significantly over time. Since the emergence of these works in the Western world in the eighteenth century, the cultural, social, and political landscapes in which they are produced have shifted dramatically. The assertion of national glories and the delineation of national identities-a key if never the sole driving force behind these vast publications-seemed not only outdated by the late twentieth century, but unenlightened, if not positively dangerous. Such a destabilisation of the imperatives that had brought national biographical dictionaries into being necessitated a rethinking of their role and purpose. Yet the history of dictionaries of national biography is not simply a journey from unreflective vessel of national supremacy to multiethnic reflection of national diversity. Dictionaries of national biography have always been reference works, serious, scholarly, and factual, as well as works of literature, able to provide readers with diversion and entertainment. Nor is their relationship with the nations they represent either settled or obvious in the twenty-first century. The cultural journey they have taken has been traversed in tandem with that of the nation itself, and that journey continues today.

\section{Collective Biography and Dictionaries of National Biography}

Collective biography has a long history, as Keith Thomas has reminded us. Well before the emergence of dictionaries of national biography as we understand them today, group biography was a flourishing genre in the Western world, produced in ancient Greece and Rome, and later in 
Renaissance Europe. Such works often collected the lives ofleaders (military, political, or religious), saints, or those engaged in a particular profession. ${ }^{9}$ Another form of collective biography, conceived in early modern Europe, was universal biography, an enterprise seeking to assemble 'the lives of all the notable people who had ever lived'. ${ }^{10}$ These works were sometimes very large, as was the Biographie Universelle, produced in France from 1810 by Louis-Gabriel Michaud, with numerous collaborators, and in its first edition (including supplements) spanning 85 volumes. ${ }^{11}$ National biography, as such, grew out of the development of nationalist ideas, and began with the 1662 publication Worthies of England, by Thomas Fuller. ${ }^{12}$

Though by no means a new development, collective national biography experienced a boom in the nineteenth century as nationalism flowered in Europe. As Thomas put it, during this period dictionaries of national biography became an obligatory accompaniment to the process of European state formation' and 'a stock way of forging national identity and generating national pride'. ${ }^{13}$ Beginning with Sweden from 1835, national biographical dictionaries were produced across Europe, including in the Netherlands, Austria, Belgium, Germany, and Denmark, as well as on the other side of the Atlantic in the United States of America. ${ }^{14}$ For Verga, these works began with the commissioning of Belgium's Biographie Nationale in 1845 . In this publication, he posited, could be seen 'a new way of writing national history' that required the production of biographies which both profiled individuals 'worth recalling for their personal merits', and 'provided an effective illustration of the Belgian national character'. ${ }^{15}$ The Biographie Nationale was, in his view, 'the first approach to writing the biography of a nation' via the lives of individuals selected to represent that national community. ${ }^{16}$ Dictionaries of national biography such as

9 Keith Thomas, Changing Conceptions of National Biography: The Oxford DNB in Historical Perspective (Cambridge: Cambridge University Press, 2005), 2-3. doi.org/10.1017/CBO97805 11497582; Julie F. Codell, 'Biographical Dictionaries', in Encyclopedia of Life Writing: Autobiographical and Biographical Forms, ed. Margaretta Jolly, vol. 1, $A-K$ (Chicago and London: Fitzroy Dearborn Publishers, 2001), 107.

10 Thomas, Changing Conceptions, 4.

11 Thomas, Changing Conceptions, 8; Christopher Smith, 'Biographie universelle; Dictionnaire de biographie française', in Jolly, Encyclopedia of Life Writing, 1:109.

12 Thomas, Changing Conceptions, 9-11.

13 Thomas, Changing Conceptions, 14.

14 Thomas, Changing Conceptions, 15.

15 Verga, 'The Dictionary is Dead', 90-91. Colin Matthew also identified the Biographie Nationale de Belgique as 'the first large scale [dictionary of national biography] in a recognizably modern format'. Colin Matthew, 'Dictionaries of National Biography', in McCalman with Parvey and Cook, National Biographies and National Identity, 3.

16 Verga, 'The Dictionary is Dead', 91. 
these displayed 'an unconcealed nationalist agenda', in Thomas's words, although their creators were also driven by other motives, such as 'the commemoration of the virtuous dead', the provision of exemplary lives to inspire people, and the entertainment and education of readers. ${ }^{17}$

Britain's Dictionary of National Biography (DNB), published from 1885, has been described as 'a belated response' to this nineteenth-century literary phenomenon. ${ }^{18}$ Yet for its first editor, Leslie Stephen, a dictionary of national biography was not merely a product of 'the "commemorative instinct"' (as the next editor, Sidney Lee, would see it), but a boon to learning at a moment when scholarship was greatly expanding. ${ }^{19}$ Moreover, the $D N B$ was, in the words of Colin Matthew - the founding editor of its successor, the Oxford Dictionary of National Biography $(O D N B)$ 'dramatically eclectic'. ${ }^{20}$ It included eccentrics and notorious figures as well as eminences, and it was vague and nonprescriptive about the precise contours of the nation it depicted. Such a lack of jingoism was perhaps a result of the dominant global position held by the United Kingdom at the time. As Thomas contended, ' $[t]$ ranquil consciousness of Britain's world superiority made [the $D N B$ ] less obviously chauvinistic than its European counterparts, for whom national independence was newer and less secure'. ${ }^{21}$ Lawrence Goldman, the third editor of the $O D N B$, similarly argued that 'the $D N B$ was not a characteristic work of its age, but something much more eclectic, broad, independent and ultimately unclassifiable'. ${ }^{22}$

Many countries outside Europe have also produced their own dictionaries of national biography. In the United States, the Dictionary of American Biography was published between 1927 and 1936, with supplements appearing until 1985; its successor, the American National Biography, appeared in 24 volumes in 1999 and is now published online and

17 Thomas, Changing Conceptions, 15-24.

18 Alison Booth, 'Fighting for Lives in the $O D N B$, or Taking Prosopography Personally', Journal of Victorian Culture 10, no. 2 (2005): 273-74. doi.org/10.3366/jvc.2005.10.2.267.

19 David Amigoni, 'Distinctively Queer Little Morsels: Imagining Distinction, Groups, and Difference in the $D N B$ and the $O D N B$ ', Journal of Victorian Culture 10, no. 2 (2005): 280. doi.org/ 10.3366/jvc.2005.10.2.279.

20 Matthew, 'Dictionaries of National Biography', 7.

21 Thomas, Changing Conceptions, 26-27.

22 Lawrence Goldman, 'A Monument to the Victorian Age? Continuity and Discontinuity in the Dictionaries of National Biography 1882-2004', Journal of Victorian Culture 11, no. 1 (2006): 118. doi.org/10.3366/jvc.2006.11.1.111. 
regularly updated. ${ }^{23}$ Established through a bequest and first published in 1966, Canada's Dictionary of Canadian Biography/Dictionnaire biographique du Canada is produced in both English and French, and to date comprises 15 print volumes and an online edition that also contains additional biographies, including from the volume currently in progress. ${ }^{24}$ The Australian Dictionary of Biography $(A D B)$ was founded in the 1950s, with its first volume also appearing in 1966. Extending thus far to 18 volumes and a supplement, the $A D B$ went online in 2006, and entries are now published first online. ${ }^{25}$ On the other side of the Tasman, the Dictionary of New Zealand Biography $(D N Z B)$ was published in five print volumes, plus a parallel series in the Māori language, between 1990 and 2000 , and has since been digitised and integrated into the online resource Te Ara-The Encyclopedia of New Zealand. ${ }^{26}$

These examples, and indeed all the dictionaries discussed in this book, are located in the English-speaking world. While several of those considered in this volume are not English language-only publications, those that are bilingual are all produced in English as well as another language. Other national dictionary projects might have been chosen for inclusion, and would have provided valuable contrasts to those discussed in these pages. The Dictionary of Swedish National Biography (Svenskt biografiskt lexicon), for example, began publication in 1917, and includes individuals 'active in Sweden, or who have acted for Sweden abroad', while in Switzerland biographies form one part of the Historical Dictionary of Switzerland (Historisches Lexikon der Schweiz/Dictionnaire historique de la Suissel Dizionario storico della Svizzera), along with families, geographical entries, and thematic or subject articles. ${ }^{27}$ Like the $O D N B$, the Neue deutsche Biographie is the successor to an earlier national biographical dictionary, the Allgemeine deutsche Biographie. Produced by the Historical Commission of the Bavarian Academy of Sciences, it focuses on 'people

23 'About the $A N B$ ' and 'Frequently Asked Questions', American National Biography Online, accessed 4 January 2017, www.anb.org/aboutanb.html and www.anb.org/qa.html.

24 'About Us', Dictionary of Canadian Biography, accessed 4 January 2017, www.biographi.ca/en/ about_us.php.

25 For the history of the $A D B$, see Melanie Nolan and Christine Fernon, eds, The ADB's Story (Canberra: ANU E Press, 2013). doi.org/10.22459/ADBS.10.2013.

26 'Dictionary of New Zealand Biography', Ministry for Culture and Heritage, accessed 4 January 2017, www.mch.govt.nz/what-we-do/websites-we-run/dictionary-new-zealand-biography.

27 'What is the Dictionary of Swedish National Biography?' Dictionary of Swedish National Biography, accessed 21 August 2018, sok.riksarkivet.se/Sbl/OmSBL.aspx; 'The History of the Historical Dictionary of Switzerland, Historisches Lexikon der Schweiz/Dictionnaire historique de la Suisse/Dizionario storico della Svizzera, accessed 21 August 2018, www.hls-dhs-dss.ch/d/english. 
from the German-speaking areas whose achievements have influenced developments in politics, the economy, social sciences, technical fields, and the arts' ${ }^{28}$ In Spain, meanwhile, the release of the first volumes of the Spanish Dictionary of Biography (Diccionario biográfico español) in 2011 was accompanied by criticism of its treatment of General Francisco Franco, among others, and it was later announced that Franco's entry would be amended in the online edition. ${ }^{29}$ Further afield, illuminating contrasts might be made with biographical traditions in Asia, Africa, or Latin America. Biography in China, for example, was for centuries an important part of dynastic histories and developed as a means of 'transmitting to posterity certain aspects of a life'. ${ }^{30}$ New trends emerged from the late nineteenth century, while since 1949 biographical writing in China has been 'shaped by the political and ideological movements' engulfing the country. ${ }^{31}$

To some extent the selection of dictionary projects discussed in this volume is accidental, shaped by practical limitations of funding, scale, and contacts, which constrained the scope of the conference from which it arises. The English-language format of the conference, and my own English-speaking background, likewise restricted the ambit of both event and book. Indeed, as evident elsewhere in this volume, issues of language can pose their own challenge for national dictionary projects, especially in nations where a variety of languages are spoken. As Barry Jones's chapter makes clear, questions of language would pose a significant difficulty for any project to produce a truly global or universal dictionary of biography. Yet there is also an intellectual reason to consider this particular group of dictionary projects together. The histories of each of the nations whose dictionaries feature in this collection are intertwined with the history of the British Empire. This historical connection to the British Empire adds

28 Gregor Hens, 'Neue Deutsche Biographie', in Encyclopedia of Life Writing: Autobiographical and Biographical Forms, ed. Margaretta Jolly, vol. 2, $L-Z$ (Chicago and London: Fitzroy Dearborn Publishers, 2001), 649.

29 Giles Tremlett, 'Spaniards Outraged Over Favourable Franco Biography', Guardian, 1 June 2011, accessed 23 August 2018, www.theguardian.com/world/2011/may/31/spaniards-outraged-favourablefranco-biography; 'Minister Tells Academy to Alter Biography After Row Over Franco Entry', El Pais, 13 June 2011, accessed 27 August 2018, elpais.com/elpais/2011/06/13/inenglish/1307942450_850210. html; James Badcock, 'General Franco to be Officially Defined by Spain as a Dictator', Telegraph, 8 April 2015, accessed 23 August 2018, www.telegraph.co.uk/news/worldnews/europe/spain/11519691/ General-Franco-to-be-officially-defined-by-Spain-as-a-dictator.html.

30 Pei-Yi Wu, 'China: to the 19th Century', in Jolly, Encyclopedia of Life Writing, 1:206-7.

31 Shao Dongfang, 'China: 19th Century to 1949', in Jolly, Encyclopedia of Life Writing, 1:208-10; Shao Dongfang, 'China: 1949 to the Present', in Jolly, Encyclopedia of Life Writing, 1:210-11. 
an additional layer-the imperial or colonial — to the national/global framework that underlies this book. To some degree, each of the projects discussed here has arguably to wrestle with the imperial strand in the history of the nation with which it deals, and each faces the question of how best to treat that imperial past in a dictionary of national biography. Such resonances between this set of dictionary ventures make them an ideal group for exploring comparatively the evolution of national biographical dictionary projects into the twenty-first century.

Dictionaries of national biography take the form of collections of concise biographies, and generally span both well-known or major historical figures, on which much has previously been written, and more minor or less well-known individuals, on whom there may be nothing previously written, or even relatively few biographical details easily available. Entries usually have a specific and at times quite prescriptive format, in order to meet the needs of a reference work to provide accurate information that is as comprehensive as possible, and which is presented in a consistent manner. At the same time, they are also literary works, and as such their producers generally seek to make them lively and readable, entertaining as well as informative. Like biography itself-as Virginia Woolf so memorably put it - they are caught between the 'granite-like solidity' of fact and the 'rainbow-like intangibility' of personality, attempting to accurately record all the salient features of a person's life and activities, and also to capture something of the spark of their personality or character, perhaps in just a few well-chosen words or a revealing anecdote. ${ }^{32}$ Despite their implication in issues of nationalism and national identity, for many of those who work in their production, it is their purpose as works of reference that is of greatest significance, shaping both broad strategic decisions such as selection choices, and editorial interventions in the articles themselves. According to Thomas, for example, the $O D N B$ has been produced primarily as 'a neutral work of reference', with subjects 'chosen for their historical importance' rather than through prisms such as nationalism or the commemoration of exemplary lives. ${ }^{33}$ Likewise, addressing the challenges of selecting 'missing persons' to be added to an existing dictionary, Christine Nicholls (the editor of the DNB's Missing Persons volume) emphasised the importance of whom readers-in that

32 Virginia Woolf, Granite and Rainbow: Essays by Virginia Woolf (London: Hogarth Press, 1958), 149 .

33 Thomas, Changing Conceptions, 36-37. 
case, people of the late twentieth century-sought to find among the entries. 'We dictionary editors', she said, 'should never forget that we are the servants of the enquirer'. ${ }^{34}$

\section{An Ever-Changing Genre}

Dictionaries of national biography may be seen as part of a wider genre of collective biographies about a nation's greats, and they share with the works in that wider genre a number of characteristic challenges, as well as displaying similar patterns of change over time. In Australia, as in other parts of the world, the current $A D B$ project was preceded by earlier efforts in collective national biography. Looking at these publications alongside the evolution of the $A D B$ can reveal something further of the cultural journeys that dictionaries of national biography have taken during the past two centuries. ${ }^{35}$ Biographical dictionaries of various kinds have been published in Australasia since the latter part of the nineteenth century. Prior to the establishment of the $A D B$ venture in 1958, these works tended to be produced by a sole author, and to focus upon individuals who held official positions or could be said in some way to represent established authority, or who produced literary or artistic works.

From the 1960s, there was a noticeable increase in the number of books published about 'famous Australians', and an even greater expansion is evident in this broad genre from the 1990s. While many of these works are not biographical dictionaries per se, and are not necessarily conceived as such, they may be understood as being part of a general category of texts about famous, significant, or influential Australians. Within this explosion of publishing on 'famous Australians', there has also been a diversification. Works produced have varied in terms of their focus, with some limited to particular occupational groups, and others seeking to highlight the

34 Christine Nicholls, 'Missing Lives: An Editor's Perspective', in McCalman with Parvey and Cook, National Biographies and National Identity, 55.

35 For a more detailed discussion of the changing nature of Australian biographical dictionaries, see Karen Fox, 'Heroes, Legends and Divas: Framing Famous Lives in Australia', in Migrant Nation: Australian Culture, Society and Identity, ed. Paul Longley Arthur (London and New York: Anthem Press, 2018), 213-34. doi.org/10.2307/j.ctt1xhr5j8.15. My discussion in this section draws on this chapter. On the history of biography and biographical dictionaries in Australia, see also Melanie Nolan, 'Country and Kin Calling? Keith Hancock, the National Dictionary Collaboration, and the Promotion of Life Writing in Australia', in Clio's Lives: Biographies and Autobiographies of Historians, eds Doug Munro and John G. Reid (Canberra: ANU Press, 2017), 247-72. doi.org/10.22459/ CL.10.2017.11; Nolan and Fernon, The ADB's Story. 
achievements and contributions to the nation of individuals from specific demographic groups, such as women or Indigenous Australians. They have varied in their audience: some have been popular works aimed at the general public, some scholarly works, and others addressed to children, often presenting those included as role models. And they have varied in authorship and production processes, encompassing both single-authored volumes in which decisions on selection and interpretation appear to have been made by one individual, and multiauthored works with more complex methods of selection, such as the Monash Biographical Dictionary of 20th Century Australia or the Bicentennial publication The People Who Made Australia Great. ${ }^{36}$ Alongside this slew of print publications have also appeared a range of web resources, often innovative and of high quality.

Inevitably, one of the most common questions fielded by those who work on biographical dictionary projects is: who gets in? Choices about selection and representation in Australian dictionaries of biography have changed significantly as Australia's place in the world has changed. Intricate interactions of nationalism and imperialism in the country's history, as well as shifting understandings of particular strands of identity - such as Britishness or Australian nationalism-have shaped these works in distinctive ways. The earliest biographical dictionaries in Australia were produced before Federation in 1901, and as such display a fluid approach to questions of inclusion related to nationality. Both J. H. Heaton's Australian Dictionary of Dates and Men of the Time (1879) and Philip Mennell's Dictionary of Australasian Biography (1892) included New Zealand as well as the six Australian colonies, a reflection of New Zealand's status as a potential partner in a federated nation. ${ }^{37}$ These works also had an imperial flavour, showcasing the achievements and development of these far-flung portions of the British Empire.

Works produced after Federation, and especially from the middle of the twentieth century following a nationalist awakening in literary and historical circles, often displayed a more overt nationalism and a greater degree of wrestling with the issue of who ought to be considered adequately

36 John Arnold and Deirdre Morris, eds, Monash Biographical Dictionary of 20th Century Australia (Port Melbourne: Reed Reference Publishing, 1994); Simon Blackall, ed., The People Who Made Australia Great (Sydney: Collins Australia, 1988).

37 J. H. Heaton, Australian Dictionary of Dates and Men of the Time: Containing the History of Australasia from 1542 to Date (London: S. W. Silver, 1879); Philip Mennell, The Dictionary of Australasian Biography, Comprising Notices of Eminent Colonists from the Inauguration of Responsible Government Down to the Present Time (London: Hutchinson, 1892). 
Australian to include. ${ }^{38}$ In the 1960 s cooperation among historians on either side of the Tasman began to dissipate, as both Australia and New Zealand began to focus more closely upon teaching, researching, and writing their own national histories. Their respective national biographical dictionaries - one beginning in the 1950s and the other in the 1980s-though not without cross-fertilisation, thus developed as largely individual national projects. ${ }^{39}$ Perhaps surprisingly, the $A D B$ has been an exception to this general tendency towards increased reflection on the nation, and on how selection choices relate to that nation; the $A D B$ provided no specific comment on the issue of who counted as 'Australian' before the publication of volume 18 in $2012 .{ }^{40}$ In the twenty-first century, this issue has taken a different cast, as questions have arisen over the place of national dictionaries in a globalised world, where transnational history has become a popular historical framework. This interplay of the national and the global or transnational is one of the themes of this book.

The issue of selection which has, perhaps, provoked most discussion and criticism for dictionaries of national biography has been that relating to demographics. Australia was remade demographically during the twentieth century, as the White Australia immigration policy was dismantled and replaced by a multicultural ideal, while other social and political currents-such as the so-called 'second wave' of feminism and the intensification of Indigenous rights movements-have also transformed the country. Historiographical developments arising out of and alongside these cultural and political changes have, meanwhile, radically reshaped the disciplines of history and biography. In particular, biographical dictionaries have come under pressure to engage with and respond to the insights of new subfields such as women's history and Indigenous history. Dictionaries produced in the nineteenth and early twentieth centuries, predictably, included small numbers of women, and even fewer figures

38 See for examples, Fred Johns, Johns's Notable Australians: Who They Are and What They Do: Brief Biographies of Men and Women of the Commonwealth (Melbourne: George Robertson, 1906); Fred Johns, An Australian Biographical Dictionary (Melbourne: Macmillan, 1934); Percival Serle, Dictionary of Australian Biography, 2 vols (Sydney: Angus and Robertson, 1949); 1000 Famous Australians (Adelaide: Rigby, 1978); Ann Atkinson, The Dictionary of Famous Australians (St Leonards: Allen and Unwin, 1992).

39 Melanie Nolan, 'The Politics of Dictionaries of Biography in New Zealand', in After the Treaty: The Settler State, Race Relations and the Exercise of Power in Colonial New Zealand: Essays in Honour of Ian McLean Wards, eds Brad Patterson, Richard S. Hill, and Kathryn Patterson (Wellington: Steele Roberts Publishers, 2016), 52-54, and an earlier version of this chapter kindly provided to the author. 40 Melanie Nolan, ed., Australian Dictionary of Biography, vol. 18, 1981-1990, L-Z (Carlton: Melbourne University Press, 2012), viii. 
not of European descent. Significant change to these patterns waited several decades, but, particularly from the 1960s and 1970s, biographical dictionaries began to feature larger numbers of women, and more entries on Indigenous Australians. ${ }^{41}$ Dictionary producers were, however, to some extent limited in their ability to remedy these imbalances, which are the product of past social and political circumstances as well as of current historical blindness. As Claudia Orange, the second general editor of the $D N Z B$, pointed out in relation to the fifth volume of the dictionary (covering the years 1941-60), the shortage of women in the book was 'probably indicative of the social conditions of the period'. ${ }^{42}$ A similar point could be made about the representation of non-European populations in national biographical dictionaries in Australia, New Zealand, or other settler colonial countries.

Although there has undoubtedly been an increase in the numbers of women and Indigenous Australians included in Australian biographical dictionaries, the issue of appropriate levels of representation has by no means been resolved. As $A D B$ general editor Nolan has observed, from the 1970 s the $A D B$ has been subject to critiques regarding groups underrepresented in the dictionary-including, besides women and Indigenous Australians, the working class-as well as to complaints that other groups are overrepresented. ${ }^{43}$ One response to such perceived flaws in general biographical dictionaries has been the production of targeted works focused on these groups. Such works are not new. Collective biographies of historical women in English, for example, may be traced to at least to the mid-eighteenth century. ${ }^{44}$ Both in Australia and internationally, however, collections of women's lives flourished in the

41 For a more detailed numerical analysis of the changing proportions of women and non-European subjects included in Australian biographical dictionaries since the 1870s, see Fox, 'Heroes, Legends and Divas', 222-26.

42 Claudia Orange, ed., The Dictionary of New Zealand Biography, vol. 5, 1941-1960 (Auckland and Wellington: Auckland University Press and the Department of Internal Affairs, 2000), ix.

43 Melanie Nolan, “Insufficiently Engineered”: A Dictionary Designed to Stand the Test of Time?' in Nolan and Fernon, The ADB's Story, 23. doi.org/10.22459/ADBS.10.2013.01.

44 Alison Booth, 'The Lessons of the Medusa: Anna Jameson and Collective Biographies of Women', Victorian Studies 42, no. 2 (1999/2000): 261. doi.org/10.2979/VIC.1999.42.2.257; Barbara Caine, Biography and History (Houndmills: Palgrave Macmillan, 2010), 54-56; Susan E. Searing, 'Biographical Reference Works For and About Women, from the Advent of the Women's Liberation Movement to the Present: An Exploratory Analysis', Library Trends 56, no. 2 (Fall 2007): 470. doi.org/10.1353/lib.2008.0009. 
wake of the revitalisation of the feminist movement from the late $1960 \mathrm{~s} .{ }^{45}$ Large numbers of publications focusing on the lives of Indigenous Australians have also been produced, especially from the 1990 s. $^{46}$ These works too have parallels elsewhere, such as the eight-volume African American National Biography in the United States. ${ }^{47}$ Targeted works have also appeared for particular occupational areas, although not necessarily in response to perceived inadequacies of representation elsewhere.

In the preceding discussion I have focused upon issues of selection and representation as they unfolded in the past, but of course these are not the only issues facing national biographical dictionary ventures in the twentyfirst century. There are a host of others, many of which were not such issues - or at least, not in the same way-for the corpus of nineteenthand twentieth-century works mentioned above. Perhaps most obviously, in the twenty-first century dictionary projects operate in a digital environment, unlike many of the endeavours discussed above. This shift to the digital has brought a range of new opportunities, but also new challenges. Sustainability is one; revisions another. Dictionary projects today often face the need not only to be funded and resourced to produce an output - one or more print volumes, or a web-based resource-but also to secure the resources needed to maintain and sustain that output. The ease of access to information, and its ever-expanding nature, as well as the ease of interaction with the public brought about by the web, have created increasing pressures to revisit and revise existing material in the light of new research, fresh interpretations, and public expectations.

45 Caine, Biography and History, 58-59; Searing, 'Biographical Reference Works', 475. Searing discusses English-language publications broadly, but the Australian subset displays a similar pattern. Examples of collective biographies of women published in Australia from the 1970s include A Sense of Purpose: Great Australian Women of the 20th Century (Port Melbourne: Reed Reference Australia, 1996); Andrea Lofthouse, Who's Who of Australian Women (North Ryde: Methuen Australia, 1982); Heather Radi, 200 Australian Women (Broadway: Women's Redress Press, [1988]).

46 For example, Alex Barlow and Marji Hill, Indigenous Heroes and Leaders (Port Melbourne: Heinemann Library, 2003); Linda Bruce, John Hilvert, and Alan Hilvert-Bruce, Indigenous Australians: Artists (South Yarra: Macmillan Education, 2004); Linda Bruce, John Hilvert, and Alan Hilvert-Bruce, Indigenous Australians: Entertainers (South Yarra: Macmillan Education, 2004); Linda Bruce, John Hilvert, and Alan Hilvert-Bruce, Indigenous Australians: Leaders (South Yarra: Macmillan Education, 2004); Linda Bruce, John Hilvert, and Alan Hilvert-Bruce, Indigenous Australians: Sportspeople (South Yarra: Macmillan Education, 2004).

47 Henry Louis Gates Jr and Evelyn Brooks Higginbotham, eds, African American National Biography, 8 vols (Oxford: Oxford University Press, 2008). 


\section{Challenges for the Twenty-First Century}

If the context for national biographical dictionaries had changed considerably by the time of the first Canberra conference in 1995, it has changed still further in the years since. In 1995 it might still have been conceivable for dictionary projects to have a future as hard copy-only publications. In 2016 it is much less so, and most dictionary projects in the English-speaking world have become online repositories as well as, or instead of, being produced as physical books. This transition to the digital is one kind of cultural journey taken by dictionaries of national biography since their emergence during the flowering of nationalism in nineteenthcentury Europe. Another has resulted in changing demographic profiles in many of these works, as their producers have become ever more alert to the need for national dictionaries to appropriately represent the diversity of the nations thus biographied. A third type of cultural journey has been driven by globalisation and the turn to transnational history writing in the academy. Although still existing as dictionaries of national biography, these projects have not entirely escaped this change in scholarly focus, and ideas for greater cooperation between them, or even for a return to the ideal of universal biography, have been raised periodically. At the 1995 conference, for example, Baigent asked whether online publishing offered the chance to bring together the various national dictionaries into a 'universal biographical dictionary'. ${ }^{48}$

All three of these cultural journeys — or we might equally describe them as challenges for the future-were discussed at the conference in Canberra in 1995, and each of them is revisited and developed in new ways in this book. Penned from different perspectives by scholars from various locations in the English-speaking world, the chapters of this book address these three key areas of challenge for national biographical dictionary projects in the twenty-first century. The book is divided into three sections: the digital challenge, the representational or diversity challenge, and the transnational or global challenge. Each chapter deals with a particular aspect of one of those cultural journeys, while also illuminating the specific situations of different dictionary endeavours around the world, and revealing the interconnected nature of these challenges, and, perhaps, the solutions to them. Most were originally presented in shorter form at the conference in Canberra in 2016, but some have been produced for this 
collection. All demonstrate the rich possibilities, deep scholarship, and lively humanism involved in producing dictionaries of national biography, and collectively they form a powerful argument for the continued value and importance of this kind of large-scale collaborative research. In 2012, Verga questioned whether or not the genre of the national biographical dictionary 'really respond[ed] to pressing historiographical issues, and our present concerns'. ${ }^{49}$ The papers gathered together in this book, delving with seriousness of thought into three key concerns of both scholars and wider society today, suggest that they do.

To begin with the digital challenge, it is clear that 20 years on from the first Canberra conference, the digital revolution that was then only nascent has now transformed scholarship, both in the ways it is conducted and in the ways it is encountered and consumed. In his chapter on the integration of the Dictionary of New Zealand Biography with the digital resource Te Ara-The Encyclopedia of New Zealand, Jock Phillips reveals how the biographies included in national dictionaries of biography can be given wider significance through linking with other online resources, such as the contextual essays contained in an encyclopedia project, as well as how the inclusion of those biographies in an encyclopedia can add depth and human richness to the stories of the nation contained in such a work. Turlough O'Riordan discusses the production of the Dictionary of Irish Biography, focusing on the transformations in both research methods and editorial and publishing practices wrought by the digital revolution. He suggests that the growth of digital resources for research, and increasing moves to present scholarly outputs online, introduce new issues that many scholars have yet to fully consider. Paradoxically, he argues that the way forward for dictionaries of national biography in this digital world is to be guided by past practices perfected in the era of hard-copy, analogue-only research and publication.

Philip Carter considers the 'purpose of national biography', presenting a positive vision of the future for dictionaries of national biography, and suggesting that these venerable reference works are 'on the cusp of significant development and opportunity'. He emphasises the significance of a curated, scholarly collection of biographies in an era of 'information overload', and argues that the function of national biographical dictionaries as platforms for presenting and enabling original research—including

49 Verga, 'The Dictionary is Dead', 100-101. 
through methods made possible by a new digital environment-ought to be more widely acknowledged and promoted. In her chapter, Australian Dictionary of Biography general editor Melanie Nolan discusses the extent to which the digital challenge, with all the new possibilities offered by digital tools, has transformed the project of producing a national biographical dictionary. She too provides an optimistic view of the potential of such technological advances, suggesting that far from undermining dictionary projects, the move to new 'digital environment[s]' may assist in meeting old challenges.

Moving to the challenge of diversity, or representation, Susan Ware draws on the lessons she learned as editor of a specialist biographical dictionary of women's lives to outline how in practical terms an editor might act on his or her commitment to increasing the gender balance of a dictionary of national biography, stressing in particular the importance of continually keeping that aim in view, given the range of pressures that may tend in the direction of the status quo. She points out that the same lessons might equally apply to the task of improving the coverage of other underrepresented groups, including ethnic minorities, as well as suggesting an aspect of the challenge of diversity that is yet to be fully comprehendedthat of the inclusion of Trans* individuals. In discussing the specialist dictionary Notable American Women alongside her experiences as general editor of the American National Biography, Ware asks whether the need for such specialist dictionaries will be obviated if national dictionaries do succeed in the task of improving their representation of women's lives. This question is at the heart of Elizabeth Ewan's chapter, which considers the part that biographical dictionaries of women may play in constructing biographies of nations, through a detailed study of the case of Scotland. She argues that biographical dictionaries of women can raise questions about 'what it has meant to be a woman in a society in the past', as well as about the ways in which those meanings have shifted over time. At the same time, in a context where no recent large-scale national biographical dictionary has been produced, she suggests that 'a wide-ranging women's biographical dictionary' can influence approaches to the history of that nation in a range of ways.

Shino Konishi takes up the issue of diversity in relation to Indigenous Australia, discussing the representation of Indigenous Australians in the Australian Dictionary of Biography, and the development of a project to produce a specialist dictionary of Indigenous Australian biography. Her chapter also raises questions as to how such a dictionary might depart 
from the conventions of national biography as practised in the past, and what implications such departures might have for the genre as a whole. Finally in this section, Dafydd Johnston examines the relationship between the Welsh and the English languages in the Y Bywgraffiadur Cymreig/ Dictionary of Welsh Biography project, from its beginnings in print up to its current online incarnation. Exploring language as a central aspect of Welsh identity, and thus of national identity, he shows how important language, and choices around it, may be for the task of writing a true national biography.

Dictionaries of national biography are of course not only a European or English-speaking world phenomenon, although for reasons of practicality it is projects in those parts of the globe upon which this book focuses. Drawing on his own lifetime experience of writing, and revising, a Dictionary of World Biography, Barry Jones considers some of the challenges involved in producing such a work. His considered experience of a lifetime's thought about such a project, and reflections on the differences between his work and that of the Chambers Biographical Dictionary, suggest that if a national biographical dictionary is difficult, a global one is even more so. In his chapter, David Cannadine reflects upon the history of the British Dictionary of National Biography, and its twenty-first-century reincarnation as the Oxford Dictionary of National Biography, revealing the ways in which both projects have showcased global or transnational lives alongside those more firmly located in place, be that local, regional, or national. He concludes that the task of global biography remains crucial today, despite both the difficulties of the task and the present 'backlash' towards globalisation. Discussing the Dictionary of Canadian Biography/Dictionnaire biographique du Canada, David A. Wilson also considers the issue of transnationalism in the production of a national biographical dictionary, and the relationship of such endeavours to global or transnational history. As a case study, he examines the Irish diaspora, demonstrating how transnational links may be both revealed and obscured in a national biographical dictionary. While recognising the difficulties of creating links between such projects, he encourages the growth of an awareness of the international contexts of both subjects' lives and dictionary production.

The 2016 Canberra conference set out to assess the extent to which dictionaries of national biography had risen to the challenge posed in 2004 by Thomas, who was then the chairman of the supervisory committee of the new $O D N B$. Since historians no longer restricted their 
attention to particular sections of the population, he suggested, there was 'no reason' why previously 'hidden lives' ought not to be included, while technological advances had removed the practical problem of being unable to encompass much larger numbers of individuals in biographical dictionaries. He raised the tantalising possibility that, therefore, '[o]ne day ... we may have a database so vast that its claim to be a true national biography will be incontrovertible'. ${ }^{50}$ Taken together, the chapters in this collection suggest that this dream is at once closer to achievement and more difficult to accomplish than it may have seemed in 2004 .

And yet, even as the 'True Biographies of Nations?' conference was being organised and held in 2016, and the chapters prepared for this book, there were signs of yet another seismic shift in global affairs, which may once again reshape the environment in which dictionaries of national biography are produced. If the movement against globalisation represented by the Brexit vote in the United Kingdom in June 2016 and the election of Donald Trump as United States president in November the same year does indeed indicate a new wave of populist antiglobalisation nationalism, as some have claimed, or even a return to more traditionally nation-focused identities and politics, what are the implications for the venture of the national biographical dictionary? Slowly being transformed in order to take account of the breaking down of national borders and identities, will these projects find it necessary to similarly reassert these markers of nationality? Matthew, the $O D N B$ 's founding editor from 1992 to 1999, suggested that, at least in Europe, nationality would yield to European Union citizenship, and that works of reference, such as biographical dictionaries, would follow suit, becoming aggregated into a worldwide dictionary of biography. ${ }^{51}$ In the post-Brexit world, this confident assertion of the end of the nation seems, at the least, somewhat unlikely. With national interests and national agendas apparently reasserting themselves, and the whole project of globalisation under attack, the future of national biographical dictionaries may well be strikingly different to that predicted by Matthew. As recently as 2012, Verga proclaimed dead the 'established model' of biographical dictionaries, whereby they were 'identified with the story of the nation-state'. ${ }^{52}$ It seems, however, that rumours of its demise may well have been vastly exaggerated.

50 Thomas, Changing Conceptions, 56.

51 Matthew, 'Dictionaries of National Biography', 17; Thomas, Changing Conceptions, 38.

52 Verga, 'The Dictionary is Dead', 92. 
This text is taken from 'True Biographies of Nations?': The Cultural Journeys of Dictionaries of National Biography, edited by Karen Fox, published 2019 by ANU Press, The Australian National University, Canberra, Australia.

doi.org/10.22459/TBN.2019.01 